\title{
EFEKTIVITAS FACEBOOK UNTUK MEDIA PROMOSI KESEHATAN
}

\author{
Vanessa Axelia Putri Sandya, Muhammad Ali Sodik \\ IIK STRADA INDONESIA \\ vanessasandyaa26@gmail.com, alisodik2012@gmail.com
}

\begin{abstract}
Abstrak
Perkembangan teknologi informasi khususnya internet telah memberikan perubahan yang berarti pada hampir setiap aspek kehidupan. Begitu juga dengan perkembangan komunikasi dan cara berinteraksi menggunakan jaringan internet. Seperti halnya facebook sebagai salah satu dari sekian banyak situs yang memfasilitasi hal tersebut. Facebook memberikan variasi baru dalam berinteraksi sosial di mana setiap orang yang melakukan interaksi tidak bertemu secara langsung, namun melalui jaringan internet. Jejaring sosial seperti facebook bisa dimanfaatkan untuk promosi kesehatan dengan menggunakan fasilitas yang disediakan seperti send a message yang telah disediakan oleh fitur yang ada di facebook. Dalam facebook dengan mudah dan sangat efektif juga kita melakuan sebuah promosi terlebih promosi kesehatan. Karena dunia facebook sangat luas dan dapat dijangkau banyak kalangan.
\end{abstract}

Kata kunci : Facebook, media promosi, kesehatan

\section{Latar Belakang}

Seiring dengan perkembangan teknologi internet, fungsi dan pemanfaatannya terus mengalami perkembangan. Selain sebagai media bisnis, internet dijadikan sebagai media untuk berinteraksi antar-pengguna internet. Perkembangan terakhir yang cukup ramai dibicarakan, bahkan sangat fenomenal adalah hadirnya situs-situs jejaring sosial atau dikenal dengan situs pertemanan. Jumlah pengguna situs pertemanan untuk setiap situsnya mencapai ratusan juta. Para anggotanya beragam, mulai dari remaja sampai orang tua. Di dalam internet banyak situs jejaring sosial yang sering digunakan untuk berkomunikasi. Di mana munculnya jaringan internet dianggap sebagai revolusi dalam dunia komunikasi dan informasi, salah satunya adalah facebook, banyak orang yang membuka internet hanya untuk mengakses situs www.facebook.com terutama bagi para remaja. Facebook dapat menghubungakan kita dengan orang-orang yang kita kenal ataupun yang tidak kita kenal. Banyak sebagian remaja yang memanfaatkan situs facebook untuk bertukar pesan atau hanya sekedar mencari teman-teman lama yang mungkin menggunkan facebook juga jadi mereka dapat berkomunikasi kembali.

Facebook adalah website Social Networking yang sangat pupuler belakangan ini. Di website ini, kita bisa melihat berita tentang bagaimana keadaan teman-teman kita, sedang apa mereka saat ini, kemarin melakukan apa dan lain-lain.Saat ini, facebook merupakan situs pertemanan nomor satu di dunia. Hal ini didasarkan pada jumlah pengunjungnya. Seperti dilaporkan oleh ComScore (Standar Resmi Pengukur Rangking juni 2008 mencapai 132,1 juta 
orang. Di Indonesia, facebook menempati urutan pertama untuk situs pertemanan, hal ini dilihat dari banyaknya orang Indonesia yang berkunjung ke facebook. Menurut situs insidefacebook.com, pertumbuhan anggota facebook dari Indonesia mencapai 64,5\% selama tahun 2008 mengalahkan pertumbuhan anggota facebook di Negara lain di Asia tenggara. Saat ini, diperkirakan jumlah anggota facebook dari Indonesia mencapai lebih dari 1 juta orang.

Perkembangan teknologi informasi khususnya internet telah memberikan perubahan yang berarti pada hampir setiap aspek kehidupan. Begitu juga dengan perkembangan komunikasi dan cara berinteraksi menggunakan jaringan internet. Seperti halnya facebook sebagai salah satu dari sekian banyak situs yang memfasilitasi hal tersebut. Facebook memberikan variasi baru dalam berinteraksi sosial di mana setiap orang yang melakukan interaksi tidak bertemu secara langsung, namun melalui jaringan internet. Jejaring sosial seperti facebook bisa dimanfaatkan untuk promosi kesehatan dengan menggunakan fasilitas yang disediakan seperti send a message yang telah disediakan oleh fitur yang ada di facebook.

\section{Kasus Masalah}

2.1 Bagaimana efektivitas fecebook dalam promosi kesehatan?

2.2 Apa saja fitur dalam fecebook?

\section{Tinjauan Pustaka}

\subsection{Efektivitas}

Efektivitas adalah suatu tingkat keberhasilan yang dihasilkan oleh seseorang atau organisasi dengan cara tertentu sesuai dengan tujuan yang hendak dicapai. Dengan kata lain, semakin banyak rencana yang berhasil dicapai maka suatu kegiatan dianggap semakin efektif.

- Bila hasil perbandingan output aktual dengan output target $<1$ maka efektivitas tidak tercapai.

- Bila hasil perbandingan output aktual dengan output target $\geq 1$ maka efektivitas tercapai.

\subsection{Media promosi}

Media promosi adalah sarana yang digunakan dalam mendukung kegiatan promosi dan pengenalan produk atau jasa kepada masyarakat. Promosi adalah suatu kegiatan dalam bidang pemasaran yang merupakan suatu komunikasi yang dilakukan oleh perusahaan kepada pembeli atau konsumen. Yang memuat berita, persuasi, dan mempengaruhi segala sesuatu mengenai barang dan jasa yang diproduksi untuk konsumen, semua kegiatan tersebut untuk meningkatkan penjualan dengan cara menarik konsumen minat dalam membuat keputusan pembelian di perusahaan.

\subsection{Kesehatan}

Kesehatan adalah kondisi kesejahteraan fisik, mental, dan sosial yang lengkap dan bukan sekadar tidak adanya penyakit atau kelemahan. Pemahaman tentang kesehatan telah bergeser seiring dengan waktu. Berkembangnya teknologi kesehatan berbasis digital telah memungkinkan setiap orang untuk mempelajari dan menilai diri mereka sendiri, dan berpartisipasi aktif dalam gerakan promosi kesehatan. Berbagai faktor sosial berpengaruh 
terhadap kondisi kesehatan, seperti perilaku individu, kondisi sosial, genetik dan biologi, perawatan kesehatan, dan lingkungan fisik.

\section{Pembahasan}

4.1 Efektivitas fecebook dalam promosi kesehatan

Facebook merupakan media paling populer sebagai sebuah media jejaring. Sebagai media dengan pengguna aktif terbanyak, Facebook sangat berpotensi sebagai media promosi karena pada laman Facebook hampir tidak ada batasan yang berarti untuk melakukan sebuah posting. Kita bisa sharing foto, artikel, suara, video, link (tautan), atau apapun. Selanjutnya, pada subbahasan ini akan difokuskan pada hasil beberapa penelitian tentang kesehatan yang meman-faatkan Facebook sebagai medianya. Penelitian pertama ter-kait media sosial Facebook adalah penelitian Bender, dkk (2011).

Penelitian berjudul "Seeking Support on Facebook: A Content Analysis of Breast Cancer Groups" ini bertujuan untuk mengetahui karakteristik tujuan, penggunaan, dan pencipta kelompok (group) Facebook yang berhubungan dengan kanker payudara.Dalam penelitian ini, peneliti melakukan searching pada situs Facebook dengan menggunakan keyword "breast 5 Facebook adalah layanan jejaring sosial online. Namanya berasal dari cancer". Peneliti membatasi analisis pada kelompok-ke-lompok yang berhubungan dengan kanker payudara, diope-rasikan dalam bahasa Inggris, dan tersedia untuk umum. Peneliti secara independen mengekstraksi tujuan kelompok dan informasi dari administrator grup, serta jumlah kontribusi anggotanya. Peneliti mengembangkan skema coding untuk memandu analisis isi (content analysis) (Bender, et al, 2011).Peneliti menemukan ada 620 grup kanker payudara di Facebook dengan total 1.090.397 anggota. Grup diciptakan untuk beragam keperluan: penggalangan dana $(44,7 \%)$, kesadaran $(38,1 \%)$, produk atau jasa yang berhubungan dengan promosi penggalangan dana (61,9\%), dan dukungan pasien $(46,7 \%)$. Kelompok kesadaran secara keseluruhan mendominasi grup ini ( $\mathrm{n}=957.289)$. Mayoritas kelompok $(85,8 \%)$ memiliki 25 kiriman dinding (wall post) atau kurang. Kelompokkelompok yang berorientasi mendukung, sebanyak $47 \%$ dibentuk oleh sekolah tinggi atau mahasiswa (Bender, et al, 2011).Berdasarkan hasil penelitian tersebut, akhirnya pe-neliti menarik kesimpulan bahwa grup Facebook telah menjadi alat yang sangat populer untuk meningkatkan kesadaran, penggalangan dana, dan pencarian dukungan yang berhubungan dengan kanker payudara, mengingat bahwa grup-grup tersebut telah menarik lebih dari satu juta pengguna Facebook (Bender, et al, 2011).Penelitian lain terkait media sosial Facebook dilakukan oleh Agung Dwi Laksono dan Ratna Dwi Wulandari (2011) tentang studi kasus pada grup Facebook "Forum Jejaring Peduli Aids". Penelitian yang dipublikasi dengan judul "Analisis Potensi Penyebaran Informasi Kesehatan melalui Jejaring Sosial” ini menyimpulkan bahwa media sosial (Facebook) sangat efektif sebagai media difusi informasi yang melampaui wilayah geografis (negara) dan administratif. Hal ini dibuktikan dengan anggota grup Facebook yang berasal dari 20 negara, meski yang terbanyak tetap berasal dari Indonesia. 
Penelitian ini juga mendapatkan fakta bahwa media sosial efektif untuk penyebaran informasi dengan target remaja dan usia produktif (18-44 tahun). Dari 2.821 anggota (per Desember 2010), sebanyak 88,27\% merupakan kelompok usia tersebut. Hal ini dapat dipahami bahwa per-kembangan teknologi informasi yang pesat dewasa ini agak sulit untuk diikuti oleh generasi yang sudah tua. Kebanyakan pengguna atau yang memanfaatkan media sosial adalah para remaja (Laksono \& Wulandari, 2011).Penelitian selanjutnya, yang terkait media sosial Facebook, berjudul "Broad Reach and Targeted Recruitment Using Facebook for an Online Survey of Young Adult Substance Use", yang dilakukan oleh Ramo dan Prochaska (2012). Penelitian ini dilakukan untuk meneliti Facebook sebagai mekanisme untuk survei pada anak muda tentang tembakau dan varian lainnya. Responden dalam penelitian ini adalah para perokok berusia 18-25 tahun yang tinggal di seluruh Amerika Serikat dan direkrut melalui Facebook. Penelitian ini mengiklankan diri dalam program Ad Facebook selama lebih dari 12 bulan (28 Februari 2010 - 28 Februari 2011).Penelitian dilakukan sebagai sebuah operational research dengan desain pembuatan materi iklan tentang kampanye antirokok dan dimuat di Facebook (Ad Facebook) sebanyak 20 jenis iklan. Dari seluruh iklan yang ditayangkan (28.683.151 iklan tayangan), diperoleh 14.808 klik (0,7\% dari pengguna Facebook yang ditargetkan) dengan total biaya iklan mencapai \$ 6.628,24. Biaya rata-rata per klik pada iklan adalah \$ 0,45 (Ramo \& Prochaska, 2012).Keberhasilan setiap iklan bervariasi. Puncak pen-capaian klik adalah 3 bulan sebelum puncak untuk tayangan iklan. Dari 69.937.080 responden, diperkirakan 2,8\% ( $\mathrm{n}=1.980 .240)$ masuk dengan menggunakan kata kunci (keyword) "tembakau" dan "ganja" pada laman Facebook. Kampanye lewat iklan ini menghasilkan persetujuan yang ditandatangani (informed consent) sebanyak 5.237 (35,4\% dari klik). Sebanyak 3.093 responden (59\%) memenuhi kriteria, dan 1.548 (50\% dari mereka yang memenuhi kriteria) menyelesaikan survei. Biaya akhir per survei setelah validasi adalah $\$ 4,28$. Mayoritas responden berasal dari kulit putih (69\%) dan laki-laki (72\%). Sampel rata-rata 8,9 batang per hari (SD 7,5), 3,8 tahun merokok (SD 2,9), dengan rata-rata sekali seumur hidup berupaya untuk berhenti merokok, dan sebanyak $48 \%$ tidak berniat untuk berhenti merokok dalam 6 bulan ke depan (Ramo \& Prochaska, 2012).

4.2 Fitur dalam fecebook

1. News Feed

Pada 2 tahun setelah kemunculannya, Facebook mengeluarkan fitur News Feed. Fitur ini memungkinkan orang-orang mendapatkan informasi terbaru yang diunggah pengikutnya ke jejaring sosial. Di awal kemunculannya, fitur ini sangat membantu para pengguna. Dikarenakan pengguna dapat mengakses informasi tak hanya dari lingkungan sekitar, juga dari belahan dunia lain.

2. Interner.org Interner.org dirilis pada tahun 2013. Keunggulan fitur ini adalah mampu menghubungkan 2/3 dari populasi dunia yang saat itu belum terhubung dengan akses internet. Internet.org juga dikenal sebagai salah satu cara untuk mengakses Facebook secara gratis. Bahkan 
dalam perkembangannya internet.org juga melalukan kerjasama dengan beberapa provider. Tentu saja hal ini membuat penggunanya dapat mengakses Facebook tanpa pulsa.

3. Safety Check

Facebook menunjukkan mereka tidak hanya memberikan layanan untuk memperluas pertemanan saja. Sebagai jejaring sosial, Facebook juga melakukan inovasi yang bisa dianggap sebagai kegiatan sosial.Melalui fitur Safety Check, Facebook membuat penggunanya dapat saling memberi kabar pada keluarga dan teman-temannya di FB bahwa mereka dalam keadaan selamat setelah adanya suatu peristiwa atau bencana alam.

4. Reaction

Nggak heran kalau Facebook bisa bertahan selama 16 tahun. Perusahaan ini selalu memberikan pembaruan keren yang membuat penggunanya betah. Salah satu fitur yang di luncurkan Facebook pada tahun 2016 adalah reaction.Fitur ini menampilkan emojiemoji yang menarik di samping tanda likes. Melalui emoji ini pengguna dapat lebih mudah mengekspresikan tanggapannya dalam suatu unggahan. Jadi perasaan itu dapat tersampaikan secara ringkas dan lebih jelas.

5. Marketplace

Tahun 2016 sepertinya menjadi salah satu masa kejayaan untuk Facebook. Selain menghadirkan emoji, FB juga memperkenalkan fitur toko alias Marketplace.Fitur ini tentu saja memudahkan para pebisnis untuk mempromosikan dagangannya. Logo fitur marketplace cukup strategis dan mudah ditemukan para pengguna.Melalui fitur ini pengguna dapat menemukan penjual dengan lokasi terdekat dari kamu. Hal ini dikarenakan fitur marketplace menggunakan geolokasi. Namun kalau kamu merasa tidak puas dengan penjual yang ada di dekatmu, kamu bisa memperluas lokasi ataupun menyaring pencarian berdasarkan harga dan juga jenis barang.

6. Facebook 360

Fitur Facebook yang satu ini rilis pada 8 Maret 2017 lalu. Didukung oleh Oculus dan Samsung Gear VR, fitur ini menjadi salah satu fitur yang kekinian. Penggunanya bisa berbagi video 360 derajat yang menakjubkan di Facebook.Daya tarik Facebook 360 sukses menarik perhatian penggunanya, terlihat ada jutaan orang yang langsung mengakses setelah tanggal peluncurannya. Fitur Facebook 360 dapat dibagikan seperti video lainnya di FB. Pengguna juga dapat menemukan konten yang sedang trending dengan lebih mudah, menyimpan file favorit, dan mengelola koleksi favorit mereka.

7. Messenger Day - The Snapchat Way

Masih diluncurkan di bulan yang sama dengan Facebook 360, Messenger Day seakanakan mendobrak publik sebagai pesaing untuk melawan Instagram Stories dan Snapchat. Hal ini dikarenakan fitur ini memiliki kemiripan dengan pendahulunya. Bahkan beberapa fitur seperti filter, stiker, dan juga tulisan akan hilang dalam 24 jam seperti media sosial lain.Untuk menemukan fitur ini, kamu bisa mengakses melalui Facebook Messenger yang sudah ada. Salah satu keuntungan fitur ini adalah mampu membantumu memeriksa 
orang-orang yang aktif untuk chatting.Selain itu pengguna juga bisa berbagi tentang apa yang mereka lakukan. Messenger Day juga semakin menarik dengan kehadiran filter interaktif yang dapat dengan mudah digunakan ke foto mereka.

8. Facebook Live

Kalau sebelumnya pengguna harus menggunakan Facebook Live API dari smartphone atau tablet, sekarang kamu sudah bisa melakukannya dari laptop ataupun komputer pribadi. Melalui aplikasi ini kamu juga bisa menambahkan komentar ke siaran langsung.

9. Advertising Capabilities

Fitur yang satu ini pas banget buat kamu yang memanfaatkan FB untuk berbisnis. Karena salah satu fitur terbaik Facebook ini merevolusi kemampuan iklan, sehingga akan semakin memudahkanmu dalam menjalankan bisnis.Saat ini pengguna juga bisa menggunakan Audience Networks untuk mengunggah iklan serta tawaran ke Facebook. Hal ini memberikan keuntungan agar audiens yang ditargetkan dapat tetap mengikuti semua informasi terbaru.

10. Video Grup

Fitur video grup akan menghubungkanmu untuk melakukan obrolan video bersama teman-teman. Meski mirip seperti Instagram, Video Grup Facebook memiliki keunggulan mampu menambahkan sekitar 50 pengguna ke dalam satu obrolan grup video. Selain itu fitur ini juga bisa membantumu untuk menambahkan filter yang menarik agar obrolan menjadi lebih seru. Oh iya, kalau kamu merasa tampilan kepala obrolan Facebook mengganggumu, sekarang kamu sudah bisa menghapusnya dengan mudah lewat pengaturan profil.

\section{Kesimpulan}

Cara promosi keseatan melalui media facebook yaitu dengan menggunakan fitur-fitur yang disediakan facebook seperti menghubungi lewat massager, mengirim pesan lewat wall dan berkomunikasi lewat kolom komentar yang ada pada updatean foto atau status. Efektivitas facebook untuk membangun hubungan interpersonal dirasa efektif . Dapat membangun hubungan interpersonal dengan teman yang sudah lama tidak bertemu, baik itu teman SD, SMP dan SMA. Dengan adanya facebook mereka bisa membangun kembali komunikasi yang lama sudah tidak terjaga agar ketika bertemu atau berjumpa secara langsung tidak canggung dan komunikasi akan berjalan sesuai dengan topik yang dibicarakan nanti. Dalam facebook dengan mudah dan sangat efektif juga kita melakuan sebuah promosi terlebih promosi kesehatan. Karena dunia facebook sangat luas dan dapat dijangkau banyak kalangan.

\section{Datar pustaka}

http://repository.uinbanten.ac.id/1998/1/SKRIPSI\%202017\%20\%28133300413\%29.pdf https://www.nesabamedia.com/pengertian-facebook/ https://www.dosenpendidikan.co.id/efektivitas-adalah/ 
https://pintek.id/blog/media-promosi-untuk-pemasaran-

online/\#: :text=Media\%20promosi\%20adalah\%20sarana\%20yang,produk\%20atau\%20jasa\%20

kepada\%20masyarakat

https://id.m.wikipedia.org/wiki/Kesehatan

https://www.brilio.net/gadget/10-fitur-facebook-terbaik-selama-16-tahun-mana-favoritmu200116n.html 